\title{
Effect of Inorganic and Organic Fertilizers on the Growth and Yield of Garlic Crop (Allium sativum L.) in Northern Ethiopia
}

\author{
Abraha Gebrekiros Assefa ${ }^{1}$, Solomon Habtu Mesgina ${ }^{1} \&$ Yirga Weldu Abrha ${ }^{1}$ \\ ${ }^{1}$ Department of Land Resources Management and Environmental Protection, Mekelle University, Mekelle, \\ Ethiopia \\ Correspondence: Abraha Gebrekiros Assefa, Department of Land Resources Management and Environmental \\ Protection, Mekelle University, Mekelle, Ethiopia. Tel: 251(0)-914-024-681. E-mail: abrshmekelle@gmail.com
}

Received: December 24, 2014 Accepted: January 29, 2015 Online Published: March 15, 2015

doi: $10.5539 /$ jas.v7n $4 \mathrm{p} 80$

URL: http://dx.doi.org/10.5539/jas.v7n4p80

\begin{abstract}
Among others, low soil fertility status is a limiting factor for crop production in the study area in particular and northern Ethiopia in general. Increment of garlic yield with balanced fertilization is a key important factor identified. However, use of correct type and rate of fertilizer applications are major problems in the study area. The study was conducted to investigate the effect of N, P, S, and $\mathrm{Zn}$ fertilizers and compost on yield and growth parameters of garlic (Allium sativum L.) and specify optimum fertilizer dose at field level. The experiment was laid out in randomized complete block design with three replications and five experimental plots (treated with N-P-S-Zn, N-P-S, N-P, compost and control) with unit plot size of $3 \mathrm{~m} \times 3.5 \mathrm{~m}=10.5 \mathrm{~m}^{2}$ and subjected to analysis of variance. The results showed that a combination of N, P, S, and $\mathrm{Zn}$ fertilizers gave a significant higher yield over the control plot $(P=0.05)$. The mean bulb yield obtained from plots fertilized with N-P-S-Zn, N-P-S, N-P fertilizers and compost was $4760,4388,4240$ and $3451 \mathrm{~kg} \mathrm{he}^{-1}$, respectively while $2996.5 \mathrm{~kg} \mathrm{he}^{-1}$ was the lowest average yield obtained from control plot. Similarly, the yield and growth parameters were increased progressively with combined application of N, P, S, and Zn. It can therefore be concluded that for increased garlic yield in the study area, application of $130 \mathrm{~kg} \mathrm{~N}, 20 \mathrm{~kg} \mathrm{P}, 21 \mathrm{~kg} \mathrm{~S}$ and $15 \mathrm{~kg} \mathrm{Zn}$ fertilizers per hectare could be needed.
\end{abstract}

Keywords: bulb yield, combined fertilizer, compost, garlic cloves

\section{Introduction}

Garlic (Allium sativum L.) was originated from central Asia about 3000 years and later spread to the Mediterranean regions (Tindal, 1986). Garlic is the main spices crop grown in Ethiopia. The annual production of garlic in Ethiopia is about 22,254.793 ton during 2012/2013 growing season and it is the second most important spice crops next to onion (FDRECSA, 2013). It is being consumed for curing many human diseases (Durak, Kavutch, \& Aytac, 2004; Pitman, 2008)0. Balanced fertilizer application is essential for the vegetative growth and, thus, for producing crops with top quality and high yields especially on soils that are cultivated continuously (Chintala, McDonald, \& Bryan, 2012a, 2012b). Garlic growers in the central high lands of Ethiopia tend to rely on fertilizer sources that contain only nitrogen $(\mathrm{N})$ and phosphorus $(\mathrm{P})$, resulting in steady decline in other nutrients in the soil. Smaller potassium (K) and sulfur (S) uptake relative to $\mathrm{N}$ uptake can predispose the crop to serious disease and insect damage (ENAIA, 2003). All the plants are characterized by a shallow root system which explains why fertilizers should be banded at $8-10 \mathrm{~cm}$ below the seed row (SOPIB, 2001). Due to the shallow root system, it is preferable to split fertilizer application (before sowing or planting, at the fully expanded leaf stage, and just before bulb formation). High nutrient availability is important during bulb formation. The bulb comprises small bulb called cloves (Wadjito, Rubiatai, \& Abidin, 1988). Availability of Nitrogen and Phosphorous is of prime importance for growing plants as it is a major and indispensable source of protein and nucleic acid molecules. It is also an integral part of chlorophyll molecules, which are responsible for photosynthesis. Sulfur also an essential plant nutrient with role in balanced fertilization and consequently in crop production is being increasingly appreciated. Sulfur performs many physiological functions like synthesis of sulfur and methionine (Baird, 1991). Sulfur application in garlic also enhances the uptake of N, P, K, and Ca by the crop (Hossain, 1997). Its pungency is due to the presence of a volatile oil (allyl propyl disulphide) (Malik, 1994). It is well known that the use of fertilizer helps in production and is a somewhat quick method for 
achieving maximum yield (Naruka \& Dhaka, 2001).

In Gumselasa irrigated fields of northern Ethiopia (the study area), farmers grow two to three crops in a same piece of land in a year. It is expected that such cropping practice leads to nutrient imbalance or depletion in the soil. Hence, evaluating the initial soil fertility status of the area is very important to recommend a balanced fertilizer dosage for a specific crop. However, it is not common practice to assess how much fertilizer remains in the field for the next crop and how much would be applied to achieve higher yield in respect of benefits in the study area. In the absence of initial soil fertility status assessment practice and location-specific fertilizer application rate, farmers of the study area apply fertilizers simply based on their local practice called blanket fertilizer recommendation. Consequently, such field level soil fertility management makes the soil heterogeneous and fertility depletes in a long run that could be accompanied by low production. Garlic being a cash crop, increment of yield with balanced fertilization is one of the identified researchable issues in the area. This study was, thus, conducted to find out optimum dosage of fertilizer for higher production in the area by assessing the deficiency or sufficiency levels of N, P, S, and Zn nutrients in the field and evaluating the effect of combined N, $\mathrm{P}, \mathrm{S}$, and $\mathrm{Zn}$ fertilizations and compost treatments on the yield and yield components of garlic crop.

\section{Materials and Methods}

\subsection{Area Description}

The study area is located in the northern highlands of Ethiopia at Gumselassa irrigation scheme $\left(13^{\circ} 14^{\prime} \mathrm{N}\right.$ and $39^{\circ} 32^{\prime} \mathrm{E}$ ) at an altitude of 1960 m.a.s.l. The scheme is situated about $4 \mathrm{~km}$ east of Adigudom town in the Tigray region. The area belongs to the "Weynadega" (characterized by an altitude of 1400-2600 m.a.s.l based on traditional classification) agro ecological zone. The rainfall in the study area is highly variable with space and time. It is in the range of 300-900 mm per year and uni-modal, with more than $85 \%$ of the rain falling within a period of four months from June to September. Drought periods of several weeks during the rainy season are also frequent (Mintesinot, Tigabu, \& Fassil, 1999). The maximum and minimum average temperatures are $28{ }^{\circ} \mathrm{C}$ and $9{ }^{\circ} \mathrm{C}$, respectively (SAERT, 1994). The largest part of the area is dominated by arable lands having a gentle slope and encircled by a smaller area with steep sloping hills. About $61 \%$ of the area is covered with black clayey soils (Mintesinot, Tigabu, \& Fassil, 1999; Table 2) having pH value ranging between 7.72 and 8.11 (Table 3).

\subsection{Methods}

The experiment was conducted in farmer's field for two consecutive irrigation seasons in 2012/2013 and 2013/2014 from February to May. The experimental plot was laid out in randomized complete block design with three replications and five treatment plots. A local garlic cultivar called 'Rie' was used as planting material. The unit plot size was $3 \mathrm{~m} \times 3.5 \mathrm{~m}=10.5 \mathrm{~m}^{2}$. The treatments consisted of three different combinations of $\mathrm{N}, \mathrm{P}, \mathrm{S}$, and Zn fertilizers (N-P, N-P-S and N-P-S-Zn) assigned to three plots, fourth plot fertilized with compost and fifth plot was a control (Table 1).

Table 1. Fertilizer application rates

\begin{tabular}{llllll}
\hline \multirow{2}{*}{ Treatments } & \multicolumn{5}{c}{ Nutrient Doses $\left(\mathrm{Kg} \mathrm{he}^{-1}\right)$} \\
\cline { 2 - 6 } & $\mathrm{N}$ & $\mathrm{P}$ & $\mathrm{S}$ & $\mathrm{Zn}$ & Compost \\
\hline $\mathrm{T}_{0}$ & 0 & 0 & 0 & 0 & 0 \\
$\mathrm{~T}_{1}$ & 130 & 20 & 0 & 0 & 0 \\
$\mathrm{~T}_{2}$ & 130 & 20 & 21 & 0 & 0 \\
$\mathrm{~T}_{3}$ & 130 & 20 & 21 & 15 & 0 \\
$\mathrm{~T}_{4}$ & 0 & 0 & 0 & 0 & 12,000 \\
\hline
\end{tabular}

Note. $\mathrm{T}_{0}$ is control; $\mathrm{T}_{1}$ is nitrogen and phosphorous; $\mathrm{T}_{2}$ is nitrogen, phosphorous and sulphur; $\mathrm{T}_{3}$ is nitrogen, phosphorous sulphur and Zinc and $\mathrm{T}_{4}$ is compost.

Two soil samples were randomly picked from each replication sites at a depth of 0-20 cm using auger to form a composite sample. The soil samples were air dried, crushed in a mortar and sieved through a $2 \mathrm{~mm}$ sieve. Chemical and physical soil analyses were done on the separates pass through $2 \mathrm{~mm}$ mesh only. The $\mathrm{pH}$ of the soils was determined in 1:2.5 soil water suspensions using a glass electrode and the electrical conductivity of the soils was measured in saturated extract (Van Reeuwijk, 1992). Soil bulk densities were determined by analyzing the 
collected undisturbed soil samples following the core sampling method (Black, 1965). The Walkley and Black method was used to determine organic carbon content of the soils (Walkley \& Black, 1934) and the organic matter content was obtained by multiplying the percent organic carbon by conversion factor of 1.724 . Total nitrogen was analyzed using the Kjeldahll method (Black, 1965). Available phosphorus was determined by Olsen method (Olsen \& Dean, 1965). Available sulfur was determined using the $\mathrm{KCl}-40$ test, where $0.25 \mathrm{M} \mathrm{KCl}$ was added to the soil and extracted at $40{ }^{\circ} \mathrm{C}$ temperature for three hours (Blair, Chinoim, Lefroy, Anderson, \& Crocker, 1991). Available zinc was determined after air-dried soils were extracted in 1\% EDTA, the filtrate was aspirated into an air-acetylene flame of an atomic absorption spectrophotometer and the absorbance was recorded (Baker, 1974). The soil particle size distribution was determined using hydrometer method (Van Reeuwijk, 1992) and classified in to its soil class on the bases of particle size (Table 2).

Fertilizer doses were calculated according to initial soil nutrient status of the experimental plots. The soil texture was determined as clay soil (Table 2). Soil $\mathrm{pH}$ was fairly alkaline, the total $\mathrm{N}$ status, available phosphorus, sulfur, and zinc were either at average or below the critical level and organic matter content of the soil was low (Table 3).

Table 2. Soil textural class of the study area according to USDA

\begin{tabular}{lllll}
\hline \multirow{2}{*}{ Sample Code } & \multicolumn{3}{c}{ Soil Separate Value } & \multirow{2}{*}{ Textural Class } \\
\cline { 2 - 4 } & \%Sand & \%Silt & \%Clay & \\
\hline Replication -1 & 17 & 21 & 62 & clay \\
Replication -2 & 17 & 19 & 64 & clay \\
Replication -3 & 21 & 21 & 58 & clay \\
\hline
\end{tabular}

Note. USDA - United States Department of Agriculture.

The entire quantity of $\mathrm{P}, \mathrm{S}, \mathrm{Zn}$ with one half of $\mathrm{N}$ were applied as basal dose at the time of final land preparation and the remaining half $\mathrm{N}$ was applied as top-dress at the fully expanded leaf stage, and just before bulb formation with side-dressing (Table 1). The sources of N, P, S, and Zn were urea, DAP, zinc-oxide and ammonium-sulfate, respectively. Sprouted garlic bulbs with diameter of 5-8 inch were planted within the first week of February in both seasons at a spacing of $20 \mathrm{~cm} \times 8 \mathrm{~cm}$ between rows and plants, respectively. All the management practices except the experimental variables were the same to all plots. Land was ploughed three times to prepare a favorable seedbed. The crop was harvested on 16 May 2013 and 15 May 2014 at maturity stage when most of the leaves dried up and bended over. Care was taken to avoid any kind of bulb injury during lifting. Data on plant parameters (plant height, total bulb weight, bulb diameter, fresh and dry matter weight of garlic) were collected properly. The collected data at various growth stages in response to the applied combinations of fertilizer and compost were recorded and analyzed. The results were subjected to analysis of variance (ANOVA) using SAS statistical software version 9.0 and treatment effects were compared using the Fisher's Least Significant Differences test at 5\% level of significance.

Table 3. Nutrient status of the initial soil

\begin{tabular}{lllll}
\hline \multirow{2}{*}{ Soil parameters } & \multicolumn{4}{c}{ Values } \\
\cline { 2 - 5 } & Replication -1 & Replication -2 & Replication -3 & Average \\
\hline $\mathrm{pH}(1: 2.5$ Soil-water) & 8.11 & 8 & 7.72 & 7.94 \\
Bulk density $\left(\mathrm{g} \mathrm{cm}^{-3}\right)$ & 1.2 & 1.34 & 1.5 & 1.35 \\
Organic matter (\%) & 2.07 & 2.6 & 2.49 & 2.39 \\
Total N (\%) & 0.113 & 0.109 & 0.108 & 0.11 \\
Available P $\left(\mathrm{mg} \mathrm{kg}^{-1}\right)$ & 2.34 & 2.1 & 3.84 & 2.76 \\
Available S (mg kg & 18.2 & 17.6 & 18.4 & 18.07 \\
Available Zn $\left(\mathrm{mg} \mathrm{kg}^{-1}\right)$ & 0.98 & 1.04 & 1.1 & 1.04 \\
\hline
\end{tabular}


All data pertaining to growth yield and yield components were collected from 5 plants in each of the 15 experimental plots of garlic. A random sampling was done from three central rows of the plot for determination of plant height. After harvesting and curing, bulb yield and yield attributes (bulb weight per plot, number of cloves per bulb, bulb diameter, bulb fresh weight and dry matter weight) were recorded.

\section{Results}

\subsection{Bulb Yield}

During the irrigation seasons of 2012/2013 and 2013/2014 in the study area, garlic showed a significant variation in yield due to application of different combinations of fertilizer treatments at $5 \%$ probability. On an average of the two irrigation seasons, combined application of $\mathrm{N}, \mathrm{P}, \mathrm{S}$, and $\mathrm{Zn}$ nutrients significantly influenced garlic yield $(P=$ 0.05 ) over others with average yield of $4760 \mathrm{~kg} \mathrm{he}^{-1}$ (Table 4). Plots fertilized with N, P, and S alone yielded up to $4388 \mathrm{~kg} \mathrm{he}^{-1}$ and plots fertilized with $\mathrm{N}$ and $\mathrm{P}$ alone yielded on an average up to $4240 \mathrm{~kg} \mathrm{he}^{-1}$. Plots fertilized with compost also yielded $3451 \mathrm{~kg} \mathrm{he}^{-1}$ on an average. The control treatment plots receiving no fertilizer, however, had the lowest yield $\left(2996.5 \mathrm{~kg} \mathrm{he}^{-1}\right)$ on average.

Table 4. Yield as affected by different combinations of fertilizer and compost

\begin{tabular}{llll}
\hline \multirow{2}{*}{ Treatments } & \multicolumn{2}{c}{ Bulb Yield $\left(\mathrm{kg} \mathrm{he}^{-1}\right)$} & \multirow{2}{*}{ Mean Yield $\left(\mathrm{kg} \mathrm{he}^{-1}\right)$} \\
\cline { 2 - 3 } & $2012 / 2013$ & $2013 / 2014$ & 2996.5 \\
\hline $\mathrm{T}_{0}$ & $2183 \mathrm{a}$ & $3810 \mathrm{c}$ & 4240.0 \\
$\mathrm{~T}_{1}$ & $3717 \mathrm{a}$ & $4762 \mathrm{~b}$ & 4388.0 \\
$\mathrm{~T}_{2}$ & $3700 \mathrm{a}$ & $5076 \mathrm{~b}$ & 4760.0 \\
$\mathrm{~T}_{3}$ & $3967 \mathrm{a}$ & $5552 \mathrm{a}$ & 3451.0 \\
$\mathrm{~T}_{4}$ & $2933 \mathrm{a}$ & $3969 \mathrm{c}$ & \\
$\mathrm{CV} \%$ & 38.53 & 4.5 & \\
\hline
\end{tabular}

Note. he is hectare, $\mathrm{T}_{0}$ is control; $\mathrm{T}_{1}$ is nitrogen and phosphorous; $\mathrm{T}_{2}$ is nitrogen, phosphorous and sulphur; $\mathrm{T}_{3}$ is nitrogen, phosphorous sulphur and Zinc and $\mathrm{T}_{4}$ is compost.

\subsection{Plant Height}

Combined application of N, P, S, and Zn showed a significant variation in plant height at different combinations including compost application (Table 5). Plant height increased gradually with increasing the combinations of nutrient types N, P, S, and Zn within the recommended doses. The tallest plants (49.47 cm in 2012/2013 and 68.67 $\mathrm{cm}$ in 2013/2014) were recorded in plots fertilized with combined N, P, S, and Zn fertilizers. Conversely, the shortest plants (43.73 cm in 2012/2013 and $46.33 \mathrm{~cm}$ in 2013/2014) were found in control plots. Plant height recorded in 2012/2013 across the treatments followed the pattern similar to those observed in 2013/2014.

\subsection{Bulb Diameter}

Application of different combinations of N, P, S, and $\mathrm{Zn}$ has created significant impact on bulb diameter of garlic (Table 5). The highest bulb diameter (3.28 cm in 2012/2013 and $5.37 \mathrm{~cm}$ in 2013/2014) was recorded in plots that received N, P, S, and Zn, while the lowest $(2.99 \mathrm{~cm}$ in $2012 / 2013$ and $3.49 \mathrm{~cm}$ in 2013/2014) was observed in control treatment.

\subsection{Bulb Fresh Weight}

A significant variation in fresh weight of bulb at harvest was observed due to application of different combinations of nutrients (Table 5). The maximum weight of fresh bulb (130.91 g in 2012/2013 and $157.31 \mathrm{~g}$ in 2013/2014) was obtained in plots fertilized with N, P, S, and Zn nutrients while the minimum weight of bulb $(100.34 \mathrm{~g}$ in 2012/2013 and 83.26 g in 2013/2014) was observed in the control treatment.

\subsection{Bulb Dry Weight}

Dry bulb weight at harvest was significantly affected by different combinations of nutrients N, P, S, and $\mathrm{Zn}$ application (Table 5). The maximum bulb dry weight (42.83 $\mathrm{g}$ in 2012/2013 and $61.93 \mathrm{~g}$ in 2013/2014) was recorded in plots that received combined N, P, S, and Zn nutrients. Minimum dry weight of bulb (32.49 $\mathrm{g}$ in 2012/2013 and $36.58 \mathrm{~g}$ in 2013/2014) was, however, recorded in the control plots. 


\subsection{Number of Cloves Per Bulb}

Application of combined fertilizers and compost significantly increased number of cloves per bulb of garlic over control in both seasons. The maximum numbers of cloves per bulb (8.69 in 2012/2013 and 11.0 in 2013/2014) were recorded in plots fertilized with N, P, S, and Zn nutrients while the minimum values (4.48 in 2012/2013 and 4.60 in 2013/2014) were recorded in plants where no fertilizers was applied (Table 5).

Table 5. Yield parameters of garlic as affected by different fertilizer combinations and compost

\begin{tabular}{|c|c|c|c|c|c|c|c|c|c|c|}
\hline \multirow{2}{*}{ Treatments } & \multicolumn{2}{|c|}{ Plant height (cm) } & \multicolumn{2}{|c|}{ Bulb diameter $(\mathrm{cm})$} & \multicolumn{2}{|c|}{ Fresh weight (gm.) } & \multicolumn{2}{|c|}{ Dry weight (gm.) } & \multicolumn{2}{|c|}{ Number of cloves per bulb } \\
\hline & 2012/2013 & 2013/2014 & 2012/2013 & 2013/2014 & $2012 / 2013$ & 2013/2014 & 2012/2013 & 2013/2014 & 2012/2013 & $2013 / 2014$ \\
\hline $\mathrm{T}_{0}$ & $43.733 b$ & $46.33 \mathrm{e}$ & $2.99 \mathrm{a}$ & $3.49 \mathrm{~d}$ & $100.34 \mathrm{a}$ & $83.260 \mathrm{~d}$ & $32.49 \mathrm{a}$ & $36.58 \mathrm{e}$ & $4.48 \mathrm{a}$ & $4.60 \mathrm{~d}$ \\
\hline $\mathrm{T}_{1}$ & $46.86 \mathrm{ab}$ & $55.47 \mathrm{c}$ & $3.10 \mathrm{a}$ & $4.44 \mathrm{~b}$ & $120.14 \mathrm{a}$ & $136.08 \mathrm{~b}$ & $40.54 \mathrm{a}$ & $51.23 \mathrm{c}$ & $5.23 \mathrm{a}$ & $5.47 \mathrm{c}$ \\
\hline $\mathrm{T}_{2}$ & $47.67 \mathrm{ab}$ & $64.67 \mathrm{~b}$ & $3.25 \mathrm{a}$ & $4.59 \mathrm{~b}$ & $120.11 \mathrm{a}$ & $154.88 \mathrm{a}$ & $41.06 \mathrm{a}$ & $53.11 \mathrm{~b}$ & $6.54 \mathrm{a}$ & $8.33 \mathrm{~b}$ \\
\hline $\mathrm{T}_{3}$ & $49.470 \mathrm{a}$ & $68.67 \mathrm{a}$ & $3.28 \mathrm{a}$ & $5.37 \mathrm{a}$ & $130.91 \mathrm{a}$ & $157.31 \mathrm{a}$ & $42.83 \mathrm{a}$ & $61.93 \mathrm{a}$ & $8.69 \mathrm{a}$ & $11.0 \mathrm{a}$ \\
\hline $\mathrm{T}_{4}$ & $46.53 \mathrm{ab}$ & $53.33 \mathrm{~d}$ & $3.01 \mathrm{a}$ & $3.88 \mathrm{c}$ & $120.95 a$ & $112.85 \mathrm{c}$ & $40.73 \mathrm{a}$ & $48.00 \mathrm{~d}$ & $6.05 \mathrm{a}$ & $7.93 \mathrm{~b}$ \\
\hline CV\% & 15 & 2.495 & 131 & 7.081 & 15.86 & 4.265 & 42.09 & 1.314 & 57.74 & 15.32 \\
\hline
\end{tabular}

Note. $\mathrm{T}_{0}$ is control; $\mathrm{T}_{1}$ is nitrogen and phosphorous; $\mathrm{T}_{2}$ is nitrogen, phosphorous and sulfur; $\mathrm{T}_{3}$ is nitrogen, phosphorous sulfur and Zinc and $\mathrm{T}_{4}$ is compost; $\mathrm{cm}$ is centimeter and gm is gram.

\section{Discussion}

Nitrogen supply to the plant increases the rate of metabolism where more carbohydrate is synthesized. This in turn increases the bulb weight and total yield as confirmed by the results of Amin, Rahim, and Hashem (1995) who reported that $100 \mathrm{~kg} \mathrm{~N}^{-1}$ resulted in maximum yield. Conversely, minimum yield was recorded in the control plot (Table 4); which could be due to low fertility status of the original soil indicating a need for balanced fertilization. Accordingly, higher yield of garlic was observed in plots fertilized with N, P, S, and Zn fertilizers over the others (Table 4). The possible justification for this higher result could be due to combined effect of the contributions of nitrogen to chlorophyll, enzymes, and proteins synthesis; as phosphorus is essential for root growth, phospho-proteins and phospho-lipids. The diameter and weight of bulbs were significantly improved with the application of $S$ up to $24 \mathrm{~kg} / \mathrm{ha}$. It also might be due to adequate nutrient supply which favored the enlargement of bulb and its weight. The result was in conformity with the findings of Nasiruddin, Farooque, and Baten (1993) that reported the application of both potassium and sulfur either individually or in combined increased plant height, number of leaves, bulb diameter, bulb weight and bulb yield. Balasubramonium, Raman, and Moorty (1979) studied that the added $\mathrm{S}$ had positive effect in increasing the yield of onion but a reduction in yield with very high dose of S was also observed.

As shown in Table 5 , there was a significant difference $(P=0.05)$ of plant height among the treatments. The observed increase in plant height particularly in the treatments fertilized with Zinc is due to the fact that zinc involves in auxin metabolism and other enzymatic reactions that increase leaf length as reported in Tisdale, Nelson, and Beaton (1985). It may be also due to the collective effect of both nitrogen and zinc that stimulate plant growth and thus increases leaf length. Significant difference $(P=0.05)$ was also observed on number of cloves per bulb among the treatments. The control plots significantly gave lower mean values on both plant height and number of cloves per bulb. Generally, significant difference of vegetative growth as affected by different combinations of nutrient elements and compost was observed among treatments.

\section{Conclusion}

The soils of Gumselassa irrigation scheme are low in organic matter and deficient in major nutrients. Consequently, yield of garlic crop including other crops growing in this area is very low. One of the major limitations responsible for the low yield in this area is indeed low soil fertility and incongruence between the capacity of the soils to provide nutrients and the amounts of nutrients added from fertilizers needed to supplement the soils. From the results obtained during the two consecutive irrigation seasons, the yield of garlic crop in terms of bulb and growth parameters increased with combined application of N, P, S and Zn. Based on the obtained results, combined application of nitrogen, phosphorous, sulfur, and zinc with the rate of $130 \mathrm{~kg}, 20 \mathrm{~kg}, 21 \mathrm{~kg}$ and $15 \mathrm{~kg}$ per hectare, 
respectively, is the most suitable and recommendable dose for maximum growth and yield of garlic in the study area.

\section{Acknowledgements}

The authors express their appreciation to the European Union and African Union cooperative research to increase food production in irrigated farming systems in Africa (EAU4FOOd) project for funding the research work and Mekelle University for facilitating the research work. The scientific legacy of the late Dr. Kiros Habtergebreal embedded in this piece of research work deserves a special praise. We would also like to thank the farmers in the study area as well as the staff members and laboratory technicians at the Mekelle Agricultural Research Center in Tigray who contributed technical and materials support to this research.

\section{References}

Amin, M. M. U., Rahim, M. A., \& Hashem, M. A. (1995). Influences of planting time and nitrogen on the growth and yield of onion. Bangladesh J. Scientific and Indust. Res., 30, 2-3.

Aujla, T. S., \& Madan, S. P. S. (1992). Response of onion (Alliuncepa) to irrigation and row spacing on deep sandy-loam soil in subtropical monsoon region. Indian J. Agril. Sciences, 62(2), 129-134.

Baird, J. (1991). Soil facts/AG-439-15. North Carolina cooperative extension service.

Baker, D. E. (1974). Determination of the relative availability H, Ca. Mg, K, Na, P, S, Fe, Mn, Zn, Cu, Al and other metals by a small exchangeable approach to soil testing. Hand Book on Reference Methods for Soil Testing (pp. 92-102). Council on Soil Testing and Plant Analysis Athens, Ga.

Balasubramonium, A. S., Raman, G. V. G., \& Moorty, K. K. K. (1979). Effect of sulfur application in the yield and quality of onion (Allium cepa L.). Agril. Res. J. Kerala, 17(1), 138-140.

Black, C. A. (1965). Method of soil analysis (Part I). American Society of Agronomy. Madison, Wisconsin, USA.

Blair, G. J., Chinoim, N., Lefroy, R. D. B., Anderson, G. C., \& Crocker, G. J. (1991). A soil sulphur test for pastures and crops. Australian Journal of Soil Research, 29, 619-626. http://dx.doi.org/10.1071/SR9910619

Chintala, R., McDonald, L. M., \& Bryan, W. B. (2012a). Effect of soil water and nutrients on productivity of Kentucky bluegrass systems in acidic soils. Journal of Plant Nutrition, 35, 288-303. http://dx.doi.org/10.1080/01904167.2012.636131

Chintala, R., McDonald, L. M., \& Bryan, W. B. (2012b). Optimization of water potential and nutrient levels for Kentucky bluegrass-white clover mixture on acidic soils. Biotechnology, Agronomy, Society and Environment, 16, 167-177.

Durak, I., Kavutch, M., \& Aytac, B. (2004). Effect of garlic extract consumptions on blood lipid and oxidant/ antioxidant parameters in human with high blood cholesterol. J. Nutr. Biochem, 15(6), 373-377. http://dx.doi.org/10.1016/j.jnutbio.2004.01.005

Ethiopian National Agricultural Input Authority (ENAIA). (2003). Crop Variety Register, 5, 101-102.

FDRECSA. (2013). Federal Democratic Republic of Ethiopia, Central Statistical Agency, agricultural sample survey of 2012/2013 (2005EC), Volume I, Report on area and production of major crops. Addis Ababa Ethiopia, statistical bulletin 532.

Hossain, M. M. (1997). Effect of different levels of nitrogen and potash on the growth and yield of garlic (M.S. Thesis, p. 65). Dept. Hort. Bangladesh Agril. Univ., Mymensingh.

Malik, M. N. (1994). Bulb crops, Onion. Horticulture (pp. 500-501). National Book Foundation Islamabad Pakistan.

Mintesinot, B., Tigabu, L., \& Fassil, K. (1999). An expletory study of farming systems under rain-fed and irrigated agriculture at Gumselassa Micro-Dam site in southern Tigray. Project MUC-RUG. Mekelle, Ethiopia.

Naruka, I. S., \& Dhaka, R. S. (2001). Effect of row spacing and nitrogen fertilization ongrowth, yield and composition of bulb in garlic (Allium sativum L.) cultivars. Journal of Spices and Aromatic Crops, 10(2), 111-117.

Nasiruddin, K. M., Farooque, A. M., \& Baten, M. A. (1993). Effect of potassium and sulphur on growth and yield of onion. Bangladesh J. Agril. Sci., 20(1), 35-40.

Olsen, S. R., \& Dean, L. A. (1965). Phosphorus. In C. A. Blach (Ed.), Methods of soil analysis (Agronomy No. 9 , pp. 1044-1046). American society of agronomy, Madison. 
Pitman, D. (2008). Medina Research Station and John Burt, Horticulture Adviser, South Perth.

SAERT. (1994). Sustainable Agriculture and Environmental Rehabilitation in Tigray. Master book of Tigray, Mekelle, Ethiopia.

SOPIB. (2001). Sulphate of Potash information board and Bulb Crops (Onions, Shallots, Garlic, Leeks). Retrieved from http://www.sopib .com

Tindal, H. D. (1986). Vegetables in the Tropics (p. 533). Macmillan Education Limited Hound Mills Basing Toke, Hamshire, England.

Tisdale, S. L., Nelson, W. L., \& Beaton, J. D. (1985). Micronutrients and other beneficial elements in soils and fertilizers. Soil fertility and fertilizers, Zinc (pp. 387-388). Macmillan Publishing Company, New York.

Van Reeuwijk, L. P. (1992). Procedure for soil analysis (2nd ed.). Int. Soil Reference and Information Center (ISRIC), the Netherlands.

Wadjito, A., Rubiatai, A., \& Abidin, Z. (1988). The effect of bulb size and spacing on the production of garlic (Allium sativum L.) cultivar Gombloh. Bulletin Penelitian Horticulture, 16(3), 63-68.

Walkley, A., \& Black, C. A. (1934). Examination of different methods for determining organic matter and the proposed modification by the chromic acid titration method. Soil Sci, 34, 29-38. http://dx.doi.org/10.1097/00010694-193401000-00003

\section{Copyrights}

Copyright for this article is retained by the author(s), with first publication rights granted to the journal.

This is an open-access article distributed under the terms and conditions of the Creative Commons Attribution license (http://creativecommons.org/licenses/by/3.0/). 